\title{
MITE DIVERSITY (ARTHROPODA: ACARI) ON EUPHORBIACEOUS PLANTS IN THREE LOCALITIES IN THE STATE OF SÃO PAULO
}

\author{
Mauricio Sergio Zacarias 1 \\ Gilberto José de Moraes ${ }^{2}$ \\ Biota Neotropica Volume (2) -http://www.biotaneotropica.org.br/v2n2/pt/abstract?article+BN00802022002 \\ Date Received 04/26/2002 \\ Revised 07/22/2002 \\ Accepted 27/07/2002 \\ 1 Present address: EPAMIG CTSM/EcoCentro, C. Postal 176, 37200-000, Lavras-MG, Brazil; \\ CNPq researcher; e-mail: zacarias@epamig.ufla.br \\ 2 Depto. de Entomologia, Fitopatologia e Zoologia Agrícola, ESALQ/USP, 13418-900, Piracicaba-SP, Brazil; \\ CNPq researcher; e-mail: gjmoraes@ carpa.ciagri.usp.br
}

\begin{abstract}
Patches of natural vegetation have been reported to play an important role in the preservation of diversity of natural enemies of pest arthropods. Euphorbiaceous plants are common in natural and regenerated ecosystems in the State of São Paulo. Those plants may act as reservoirs of phytophagous mites and their respective natural enemies, both of which are also found on cultivated plants of the same family. The objective of the work reported in this paper was to study the diversity of mite species on euphorbiaceous plants in three regions of the State of São Paulo, and to compare the similarities between those regions in relation to the composition of the mite fauna they harbor. A total of 31,603 mites belonging to 105 species in 74 genera and 16 families were collected. Twenty one of those species belong to families composed essentially of phytophages (Diptilomiopidae, Eriophyidae, Tenuipalpidae and Tetranychidae) and 43, to families composed essentially of predaceous organisms (Ameroseiidae, Ascidae, Cheyletidae, Cunaxidae, Eupalopsellidae, Stigmaeidae and Phytoseiidae). The remaining species belong to families composed of species with diverse or inadequately known feeding habits, which are here categorized as "generalists" (Acaridae, Eupodidae, Tarsonemidae, Tydeidae and Winterschmidtiidae). The plants considered in the study were classified in two groups according to the mite fauna they harbor. Plants of the Group 1 had on the average higher diversity, uniformity and species richness than the Group 2. The only species commonly exploited commercially that was considered in this study, the rubber tree, had high similarity with the remaining plants of the same locality in which they were found, indicating a flux of mites between the plants considered in the study. None of the most important mite pests of rubber trees was found on other euphorbiaceous plants considered in this study. The result of this study may help in the selection of prospective predaceous mites to be tested in applied biological control projects for the control of the major mite pests on rubber tree.
\end{abstract}

Key Words: Biological control, Acari, Euphorbiaceae, biodiversity, mites, rubber tree.

\section{Resumo}

Há muitos relatos do importante papel de remanescentes de vegetação naturais na preservação da diversidade de inimigos naturais de artrópodes pragas. Plantas da família Euphorbiaceae são comuns em ecossistemas naturais e regenerados no Estado de São Paulo. Essas plantas podem agir como reservatórios de ácaros fitófagos e seus respectivos inimigos naturais, também encontrados em plantas cultivadas da mesma família. O objetivo do presente trabalho foi estudar a diversidade de espécies de ácaros em euforbiáceas de três regiões do Estado de São Paulo, e comparar a similaridade entre essas regiões em relação à composição da fauna de ácaros que elas abrigam. Um total de 31.603 ácaros pertencentes a 105 espécies em 74 gêneros e 16 famílias foram coletados. Vinte e uma dessas espécies pertencem a famílias compostas essencialmente por organismos fitófagos (Diptilomiopidae, Eriophyidae, Tenuipalpidae e Tetranychidae) e 43, a famílias compostas essencialmente por organismos predadores (Ameroseiidae, Ascidae, Cheyletidae, Cunaxidae, Eupalopsellidae, Stigmaeidae e Phytoseiidae). As espécies restantes pertencem a famílias compostas por espécies de hábitos alimentares diversos ou inadequadamente conhecidos, as quais são categorizadas neste estudo como "generalistas" (Acaridae, Eupodidae, Tarsonemidae, Tydeidae e Winterschmidtiidae). As plantas consideradas no estudo foram classificadas em dois grupos de acordo com a fauna de ácaros que abrigam. Plantas do Grupo 1 tiveram em média diversidade, uniformidade e riqueza de espécies mais altas que o Grupo 2. A única espécie comumente explorada comercialmente que foi considerada neste estudo, a seringueira, teve alta similaridade com as plantas restantes da mesma localidade em que foram encontradas, indicando um fluxo de ácaros entre as plantas consideradas no estudo. Nenhum dos ácaros praga mais importantes em seringueiras foi encontrado nas demais euforbiáceas consideradas neste estudo. O resultado deste estudo pode ajudar na seleção de prováveis ácaros predadores para serem testados em projetos de controle biológico aplicado para o controle dos principais ácaros praga em seringueiras.

Palavras-chave: Controle biológico, Acari, Euphorbiaceae, biodiversidade, ácaros, seringueira. 


\section{INTRODUCTION}

Arguments for the conservation of biodiversity are generally related to the risk of extinction of large animals and certain plant species. Concurrently, considerable efforts towards conservation have dealt with organisms of immediate possible use for food, fiber, source of medicines, etc. Less noticeable organisms, especially arthropods, generally receive little or no attention. This probably explains the limited attention given to mites in natural habitats in Brazil.

Stability of a community usually increases with the increasing diversity of organisms in each system (Andow 1991). Alterations in the natural condition of a given system may allow a usually rare species to reach very high levels and to cause unpredictable effects (Silveira Neto et al. 1976). Through the years, man has simplified the structure of the environment over extensive areas, reducing the degree of natural biodiversity in explored areas by promoting the development of a small number of plant species of economic interest. The extreme is reached in areas of monocultures, which is instituted for maximum energy fixation and immediate ease of production (Altieri 1987). Such changes often include the exploitation of introduced crops, frequently in areas not appropriate for their cultivation. The result is the establishment of artificial, unsustainable ecosystems that require constant human interference. One of the most immediate results of monocultures is increased plant health problems due to disruptions of the natural equilibrium between organisms in natural ecosystems that is normally produced by natural control (Delucchi 1989, Costa 1993). Natural control is based on the collective forces of the environment that maintain the population of a given organism within historical levels lower than what could occur given its natural capacity for increase. It includes the action of climate, depletion or deterioration of feeding resources, competition and natural enemies (Van den Bosch et al. 1982).

The different degrees of interference in the environment for the purpose of agriculture produce a range of disturbances in relation to pest problems that lead growers to adopt different types of control practices, from disruptive use of chemical pesticides to more natural use of biological control agents. The latter include practices that promote conservation of natural enemies through the adoption of adequate agricultural practices and or adequate systems management. Proper management of ecosystems should lead to the maintenance of the genetic variability of each natural enemy species, which from a pragmatic point of view could meet present and future needs in pest control (Lasalle \& Gauld 1991).

Conservation of areas of natural vegetation near cultivated areas may play an important role as a strategy for the conservation of native natural enemies of agricultural pests. The former are commonly referred to as "refuge stations" in the literature. Several studies have shown the practical importance of refuge areas as reservoirs of these natural enemies, which periodically move from these refugia to nearby agro-ecosystems (Altieri 1994). From an applied point of view, natural enemies of pests find alternative feeding substrates in refugia that allow them to bridge unfavorable periods in nearby crops (Altieri 1994). From an ecological point of view, some crops may be temporarily exploited by pests which in turn serve as prey or host for natural enemies (predators, parasites or pathogens) that live primarily in refuge areas. Crops that do not support these natural enemies permanently because of the cropping system involved may thus benefit from nearby refuge stations (Altieri 1994). Researchers have shown that both the size of each refuge station and the distance between them are important in the maintenance of diversity of the natural enemies of pests they contain (Brown Jr. 1997).

Refuge stations are also important for the maintenance of little known or unknown natural enemies of agricultural pests. For different reasons, new pests show up from time to time, and their control may be dependent on the natural enemies (predators, parasites and pathogens) present in the refuge stations.

Some plants of the family Euphorbiaceae are commercially important in Brazil and other parts of the world. One of the most outstanding examples is the rubber tree, Hevea brasiliensis (H.B.K.) M. Arg.. Plants of this family are common in natural and regenerated ecosystems in the State of São Paulo (Nogueira 1976, Cesar \& Leitão Filho 1990, Salis et al. 1994) where they may harbor phytophagous mites and their respective natural enemies, both of which may now or in the future be found on cultivated plants of the same family.

Few papers have been published on the mite fauna of rubber trees. Feres (2000) reported 28 species of mites in 24 genera and 11 families on Hevea species. Severe damage caused by mites to rubber trees has been reported in midwestern and southeastern Brazil. The most significant damage has been attributed to Calacarus heveae Feres (Eriophyidae) and Tenuipalpusheveae Baker (Tenuipalpidae) (Feres 1992, N.J. Ferla \& G.J. Moraes, unpublished). The former species was described from a large population collected in the State of São Paulo, and it was later found in high numbers in the State of Mato Grosso (N.J. Ferla \& G.J. Moraes, unpublished). C. haveae was also recently collected from a small leaf sample from the Amazonas (Feres 2001), which is located in the region of origin of the rubber tree. T. heveae was originally described from the State of Pará, also in the region of origin of the rubber tree, but it is now known from Goiás, Mato Grosso and São Paulo (Pontier \& Flechtmann 1999; G.J. de Moraes, unpublished observation).

It is possible that $C$. heveae and $T$. heveae reached pest status after having been introduced to the midwestern and southeastern regions of Brazil. Alternatively, they could have already been present on other euphorbiaceous plants in those regions, from which they moved to rubber tree. The study of the mite fauna on euphorbiaceous plants may help in clarifying the origin of 
these mites as well as of other pest mite species on other cultivated euphorbiaceous plants. It may also help in the identification of prospective natural enemies to be used against them.

The objective of this study was to evaluate the diversity of mites on common euphorbiaceous trees in three localities of the State of São Paulo.

\section{MATERIAL AND METHODS}

Samplings were conducted in the following localities: Pariquera-Açu: Estação Experimental J. Cione, of Instituto Agronômico de Campinas, at 24S 36'50", 47W 53'00"; Cananéia: along Rodovia SP-226, 24S 55'00", 47W 50'00"; and Piracicaba: campus of Escola Superior de Agricultura Luiz de Queiroz, 22S 42'30", 47W 37'40". Pariquera-Açu and Cananéia were selected for being located within a very extensive patch of Mata Atlântica (forest of the coastal plain in Pariquera-Açu and "restinga" forest in Cananéia). Piracicaba was selected for having a diversity of native and introduced euphorbiaceous plants as well as a patch of Mata Atlântica (semi-deciduous forest), and for logistical reasons.

The number of plants sampled in each region varied according to their availability, up to a predetermined maximum of four plants per locality. A total of 49 euphorbiaceous plants belonging to 12 species in nine genera were sampled, as follows: Piracicaba: Alchornea glandulosa Poepp. \& Endl. (three plants), Alchornea sidifolia M. Arg. (one plant), Croton floribundus Spreng. (four plants), Croton urucurana Baill. (two plants), Hevea brasiliensis (H.B.K.) M. Arg. clone 527-A (rubber tree, four plants), Hura crepitans Linn. (two plants), Joannesia princeps Vell. (four plants) and Pachystroma longifolium M. Arg. (four plants); Pariquera-Açu: A. glandulosa (two plants), A. sidifolia (two plants), Alchornea triplinervea $\mathrm{M}$. Arg. (four plants), Aparisthmium cordatum (A. Juss.) Baill. (four plants), $H$. brasiliensis clone C7 (four plants), Sebastiania sp. (four plants); Cananéia: A. triplinervea (two plants), Pera glabrata (Schott) Baill. (three plants).

Samplings were conducted in April 1998 in Pariquera-Açu and Cananéia and in June 1998 in Piracicaba, and consisted of leaves collected up to a height of $6 \mathrm{~m}$. Three categories of leaf sizes were defined to determine the number of leaves to be collected from each plant species within a region: small 40 , median 30 , and large - 20 leaves. In every case, half of the leaves were sampled from the distal $5 \mathrm{~cm}$ of a branch while the remaining were sampled from other, non-senescent leaves. The species in each category were: small leaves: $A$. triplinervea and $P$. glabrata from Cananéia and Sebastiania sp. from Pariquera-Açu; median leaves: $A$. triplinervea from Pariquera-Açu, A. glandulosa and $A$. sidifolia from Pariquera-Açu and Piracicaba, $C$. urucurana, $H$. crepitans and $P$. longifolium from Piracicaba; and large leaves: A. cordatum from PariqueraAçu, C. floribundus, J. princeps from Piracicaba, and $H$. brasiliensis (from Pariquera-Açu and Piracicaba).
Leaves of each plant were put in a paper bag which in turn was put in a plastic bag. They were transported to a laboratory in a cool box $\left(15-21^{\circ} \mathrm{C}\right)$ and then stored at ca. $10^{\circ} \mathrm{C}$ for up to a week before examination under a stereomicroscope. Mites of the superfamily Eriophyoidea were collected with a brush while others were collected with a mite sucking device (Zacarias \& Oliveira 2000). All samples from Pariquera-Açu and Cananéia as well as samples of $H$. crepitans and $A$. sidifolia from Piracicaba were processed in this way. Because of the very high populations, mites on other plants from Piracicaba were collected by washing the leaves with Keifer's sorbitol/alcohol solution (Jeppson et al. 1975), similarly to what was described by Krantz (1978). For identification, mites were mounted in Hoyer's medium except for eriophyoids, which were mounted in a modified Berlese mounting medium (Jeppson et al. 1975, Amrine \& Manson 1996).

For each species found in large numbers (over ca. 150 individuals), only a subsample corresponding to ca. $10 \%$ of the total number collected was mounted for identification. These mites were counted and the resulting number was multiplied by 10 for estimation of the corresponding total number in the initial sample. Mite diversity was determined by Shannon-Weiner index. Species richness and uniformity of species were determined by the indices of Pielou (Odum 1988). All indices were calculated using $\log _{10}$. Mountford similarity indices between plant species according to the mite faunistic composition also were determined (Silveira Neto et al. 1976).

Representative specimens of each determined species were deposited in the mite reference collection of Departamento de Entomologia, Fitopatologia e Zoologia Agrícola, Escola Superior de Agricultura Luiz de Queiroz, Universidade de São Paulo, Piracicaba-SP, Brazil.

\section{RESULTS AND DISCUSSION}

A total of 31,603 mites belonging to 105 species representing 74 genera in 16 families were collected (Table 1). Twenty one of these species belong to families composed essentially of phytophagous forms (Diptilomiopidae, Eriophyidae, Tenuipalpidae and Tetranychidae) and 43 to families composed essentially of predaceous forms (Ameroseiidae, Ascidae, Cheyletidae, Cunaxidae, Eupalopsellidae, Stigmaeidae and Phytoseiidae). The remaining species belong to families of diverse or inadequately known feeding habits, which are here categorized as "generalists" (Acaridae, Eupodidae, Tarsonemidae, Tydeidae and Winterschmidtiidae). Generalists are thought to comprise detritivorous, algivorous, fungivorous, bacteriophagous and pollenophagous organisms (Walter\& O'Dowd 1995).

Analysis of the similarities between plant species based on the mite species they harbor in common indicated the presence of two groups (Figure 1): Group 1, composed of the plant species of Pariquera-Açu and 


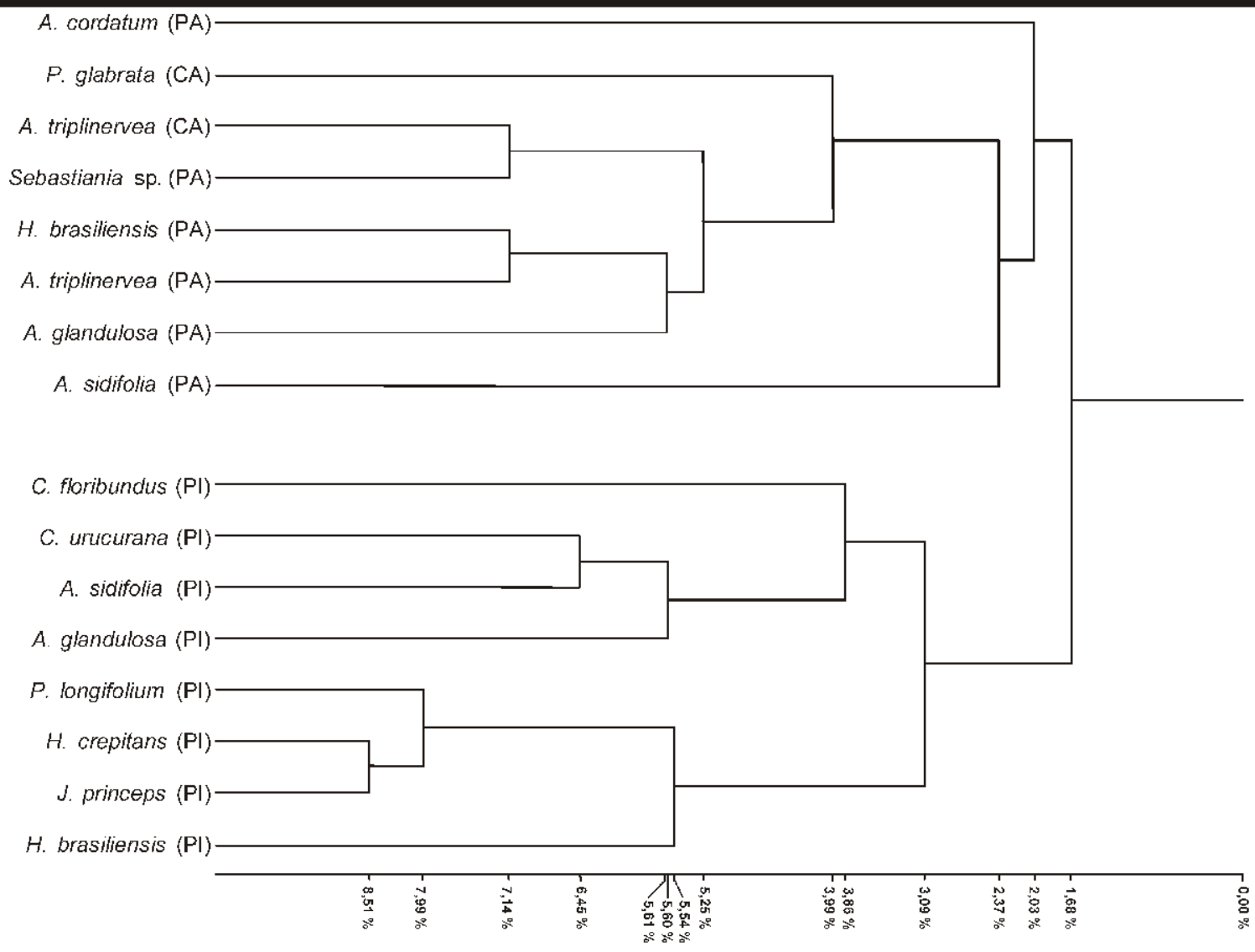

Figure 1. Aggregation of euphorbiaceous plants (Euphorbiaceae) of tthree localities of the State of São Paulo (Cananéia = CA, Pariquera-Açu = PA and Piracicaba $=$ PI) according to Mountford similarity indices relative to associated mite species.

Cananéia, and Group 2, composed of the plant species of Piracicaba. The composition of these groups may be largely a function of the different abiotic factors prevailing in each locality as determined by their geographic location, the different plant community composition in each locality (in addition to the plant species considered in the study), and/or the influence of the alterations done by man, which is more intense in Piracicaba than in other two regions.

A distinct subgroup in the Group 1 was evident, and comprised by the plant species $P$. glabrata, Sebastiania sp., H. brasiliensis, A. glandulosa and A. triplinervea (from Cananéia and Pariquera-Açu). The predaceous phytoseiid mite Typhlodromips cananeiensis Gondim Jr. \& Moraes was found on all plant species in this subgroup, and only on those plants. Concurrently, this was the most abundant predator on $H$. brasiliensis of the Group 1. A. cordatum and A. sidifolia were distinct within the group, in having the highest proportions of exclusive mite species in the group (35.0\% and $21.1 \%$, respectively)(Table 1 ).

Two subgroups were distinguished in the Group 2. The first was composed of $C$. floribundus, C. urucurana, A. sidifolia and A. glandulosa, and the second of $P$. longifolium, $H$. crepitans, J. princeps and $H$. brasiliensis. The phytoseiid Amblyseius neochiapensis Lofego, Moraes $\&$ McMurtry was found on all plants of the first subgroup, and only on those plants; the phytoseiids Typhlodromina camelliae (Chant \& Yoshida-Shaul) and Euseius citrifolius Denmark \& Muma were collected on all plants of the second subgroup, and exclusively on those plants; $T$. camelliae was the most abundant predaceous mite on $H$. brasiliensis of the Group 2.

The main factors determining the two subgroups within the Group 2 seem to be related to the precise location from where the samples were collected. The first subgroup corresponded to plants of natural remnants along the "Piracicamirim" stream, while the second subgroup included plants grown in the park of the campus or in a stand of $H$. brasiliensis.

About 10 times more mites $(N)$ were found in the Group 2 than in the Group 1 (Table 2). However, a statistical comparison between these numbers is not appropriate because of the methodology used in the study. Despite such difference, the number of species $(S)$ was about the same for both groups; also similar were the total numbers of predaceous specimens and species $\left(N_{\mathrm{p}}\right.$ and $\left.S_{\mathrm{p}}\right)$ in each group. The total numbers of phytophagous specimens and species $\left(N_{\mathrm{f}}\right.$ and $\left.S_{\mathrm{f}}\right)$ were considerably larger in the Group 2. Despite having higher total numbers of generalist specimens $\left(N_{\mathrm{g}}\right)$, the Group 2 had lower numbers of generalist species $\left(S_{\mathrm{g}}\right)$.

For the Group 1, $8.7 \%$ of the species were classified as phytophagous and $52.0 \%$, as predators, 
whereas for the Group 2, $72.9 \%$ e of the species were classified as phytophagous and $4.8 \%$, as predators. In the latter group, most of the phytophagous species belonged to the family Eriophyidae. Generalist species comprised $39.4 \%$ in the former and $22.4 \%$ in the latter group. The larger proportion of predaceous species for the Group 1 is related to the low absolute numbers of generalist and (mainly) phytophagous mites collected on those plants, in comparison to what was observed for the Group 2. Practically the same absolute numbers of predaceous mites were observed in both groups.

Looking specifically at $H$. brasiliensis (rubber tree), phytophagous and predaceous species consisted of 29.5 and $6.0 \%$ in the Group 2, and 11.3 and $27.6 \%$, in the Group 1, respectively; the proportion of generalist species was about the same in those groups $(64.5 \%$ and $61.1 \%$, respectively).

The differences between groups is apparently much smaller in relation to the biomass of the mites collected. The predominant predaceous mites collected represented the family Phytoseiidae, whose representatives are much larger than the predominant phytophagous mites which, in Piracicaba, belonged to the superfamily Eriophyoidea. Although not quantified, the microflora (lichen, moss) was notably more abundant on the leaves of plants of the Group 1. This difference might be related to the larger diversity of generalist mites in that sample series. However, the number of generalist specimens was not larger.

Mite species diversity indices $(H)$ of the plants of the Group 1 and Group 2 varied from 0.80 to 1.25 and from 0.22 to 0.92 , respectively. The diversity of the former (1.54) was considerably higher than that of the latter (1.12). Only A. glandulosa of the latter had higher diversity than a couple of plants of the former. In the Group 1, A. glandulosa had the highest mite diversity (1.25). Most of the difference was related to the generalist mite species $\left(H_{\mathrm{g}}\right)$ (Table 2).

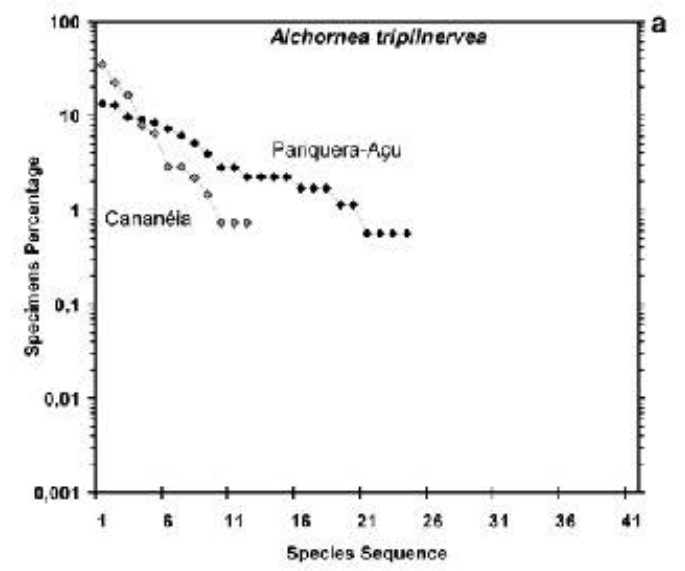

Uniformity $(e)$ and species richness $(d)$ were also higher for plants of the Group 1 (Table 2). Again, similarly to what was observed in relation to species diversity, most of the difference was related to the generalist mite species ( $e_{g}$ and $d_{g}$, respectively).

Mite species richness could be expected to be higher on plants of the Group 2 because of "border effect" (Odum 1988, Brown Jr. 1997); sampled plants of this group were located in fragmented woody areas, in contrast to plants of the Group 1, located in extensive woody areas. However, considering the plant species occurring concurrently in both groups (A. glandulosa, A. sidifolia and H. brasiliensis), this was not observed. Such a result does not necessarily negate with the border effect principle, which is normally evaluated by contrasting species diversity and richness along the edges and within a given plot.

All plants of the Group 1 had dominancediversity curves with less pronounced inclination (Figure 2a-g), indicating higher diversity and lower dominance of particular mite species over others. On rubber trees from Piracicaba, $85 \%$ of the collected specimens referred to just two species, the tydeid Lorryia sp. 1 and the eriophyid $C$. heveae (58,2 and $27 \%$ of the total, respectively); on the same plant species from Pariquera-Açu, only $50.2 \%$ of the specimens collected referred to the two most abundant species, the tydeid Lorryia formosa Cooreman and the phytoseiid T. cananeiensis (29.7 and 20,5\% of the total, respectively).

The lower diversity and the more pronounced inclination of the dominance-diversity curves for plants of the Group 2 (Figure 2b-d and 2h-l) suggest a higher disturbance in that region. This is clearly the case. The campus of Escola Superior de Agricultura Luiz de Queiroz is situated in a woody area surrounded by the city of Piracicaba on one side and sugarcane fields on the others. Small, sparse patches of native vegetation are found in Piracicaba and the surrounding municipalities, which are largely covered by sugarcane fields.

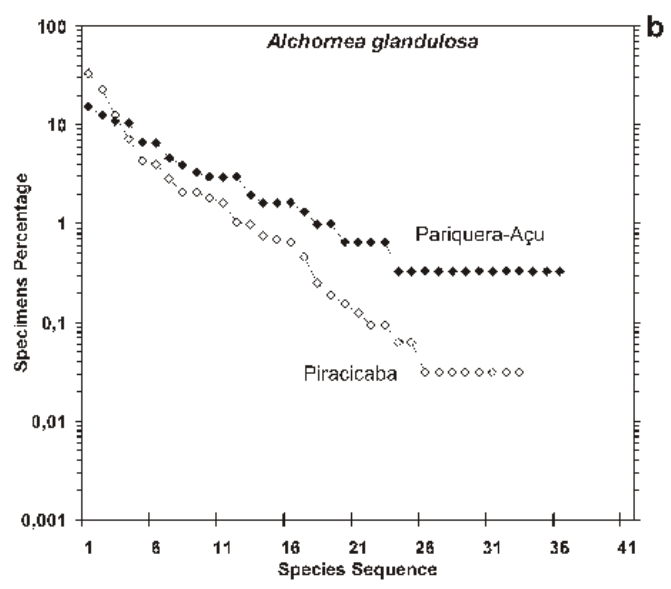



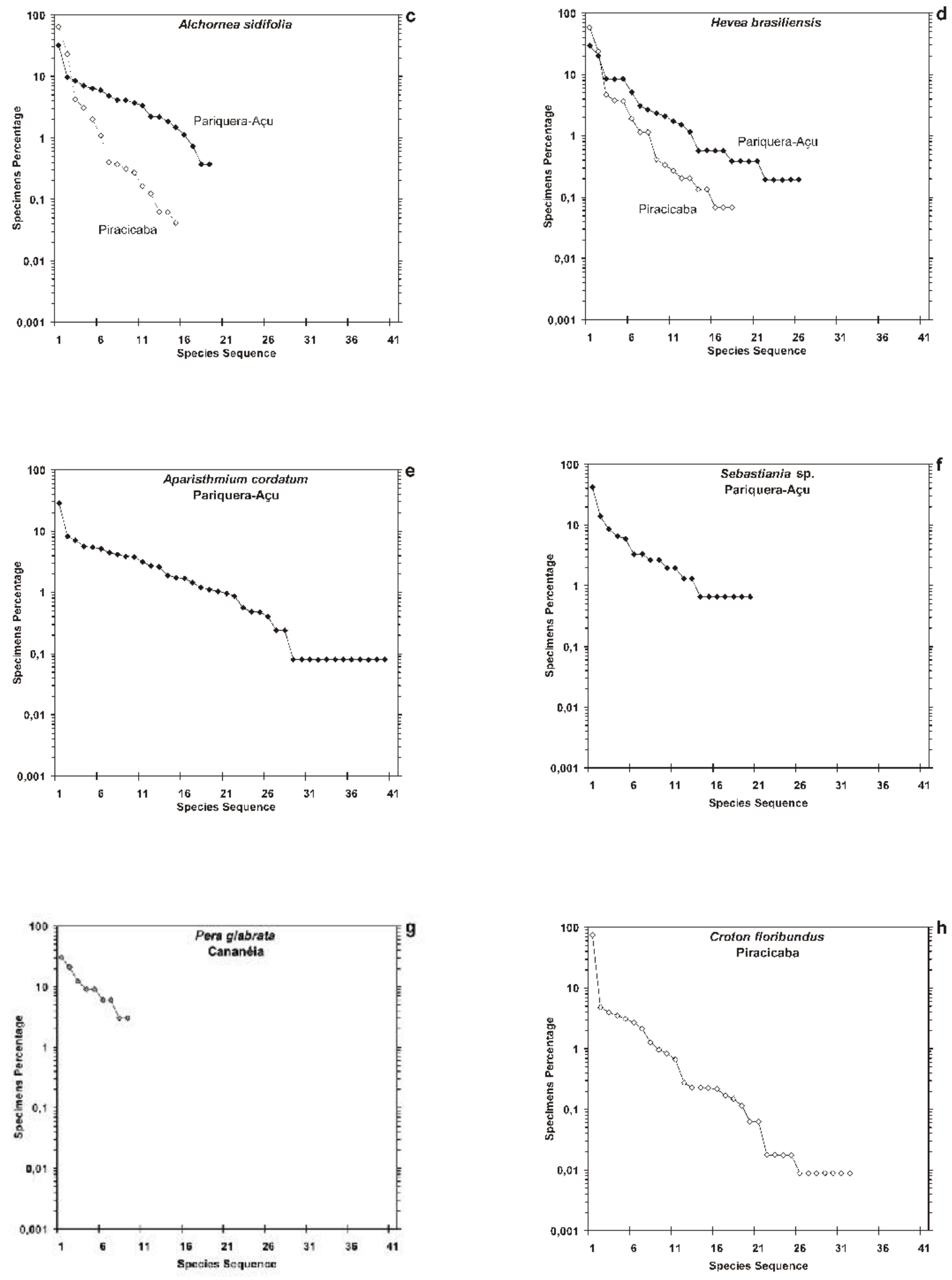

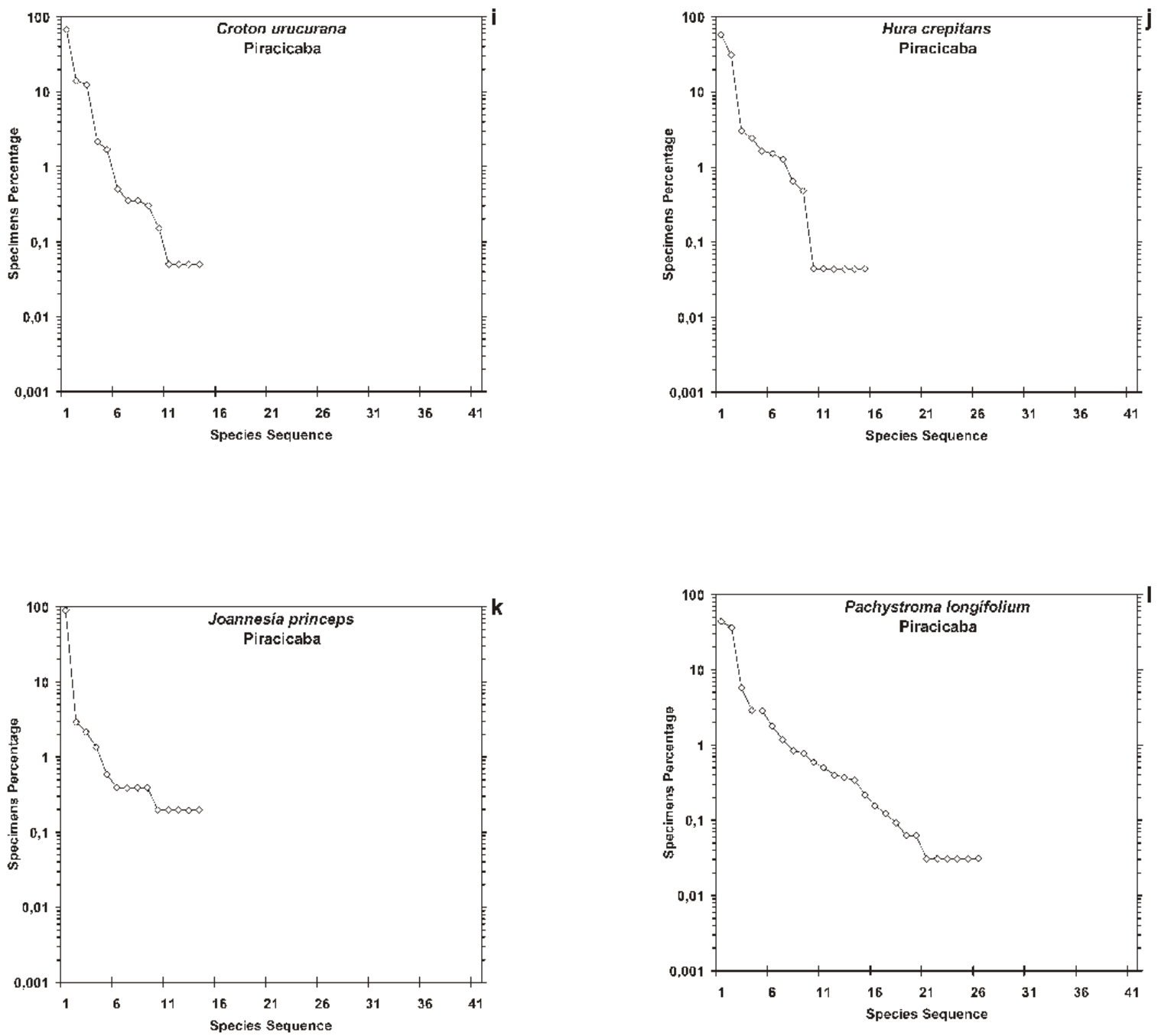

Figures 2. Dominance-diversity curves of mite species collected on euphorbiaceous plants (Euphorbiaceae) in three localities of the State of São Paulo (Cananéia, Pariquera-Açu and Piracicaba) in 1998.

Natural stress (extreme meteorological condition, for example) or the stress resulting from human activities tend to produce more pronounced inclination in dominance-diversity curves. Thus, such curves can be used to estimate the effect of disturbance on the composition of a community (Odum 1988). In places where the stressing factors are stronger, diversity tends to be reduced, i.e., the number of specimens of the dominant species tends to increase, while the numbers of species and of specimens of the rarer species tend to decline (Silveira Neto et al. 1976).

The rubber tree was the only plant species studied that is presently grown commercially. Most of the commercial exploitation of this species in São Paulo is done in the northwestern part of the State, which is more similar to Piracicaba than to the Pariquera-Açu region in relation to level of human interference. None of the known species of mites considered to be pests of rubber tree was found in this study in any of the sampled plants. A few specimens belonging to the same genera as the two most important mite pests of rubber tree in Brazil, C. heveae and $T$. heveae, were collected on A. cordatum and $C$. floribundus, respectively. However, they represented other species (Table 1). Although we did not find any alternative host to those two pest species, it is still possible that other euphorbiaceous plants found in São Paulo but not sampled in this study could serve as host to $C$. heveae and T. heveae, from which the mites could have moved to rubber trees.

The results of the present study indicated that fewer problems with phytophagous mites on rubber trees would be expected to occur in the Pariquera-Açu region as a consequence of an expected higher influx of predaceous mites from the surrounding vegetation. This suggests that reforestation could significantly contribute to a more natural control of serious mite pests of rubber trees in São Paulo State. The results may also be useful for the selection of predaceous mites to be considered for use in applied 
biological control projects against rubber tree mite pests.

\section{ACKNOWLEDGEMENTS}

To C.H.W. Flechtmann (ESALQ-USP) and R.J.F. Feres (IBILCE-UNESP) for the identification of mites in the superfamily Eriophyoidea. To R.R. Rodrigues and V.V. Souza (ESALQ-USP) for helping in the identification of the plant species considered in this study. To A.L. Lourenção and to Instituto Agronômico de Campinas for their collaboration in this work. This project was financed by the State of São Paulo Research Foundation (FAPESP), within the BIOTA/FAPESP The Biodiversity Virtual Institute Program (www.biotasp.org.br), by CAPES "Coordenação de Aperfeiçoamento de Pessoal de Nível Superior" (Ministério da Educação Brazil) and PRONEX (Ministério da Ciência e Tecnologia-Brazil).

\section{LITERATURE}

ALTIERI, M.A. 1987. The agroecosystem: determinants, resources and processes. In Agroecology. The scientific basis of alternative agriculture (M.A. Altieri, ed.). Westview Press, Boulder, p. 29-45.

ALTIERI, M.A. 1994. Biodiversity and pest management in agroecosystems. Food Products Press, New York. $185 \mathrm{p}$.

AMRINE Jr., J.W. \& MANSON, D.M.C. 1996. Preparation, mounting and descriptive study of eriophyoid mites. In Eriophyoid Mites: Their Biology, Natural Enemies and Control. (E.E. Lindquist, M.W. Sabelis \& J. Bruin, ed.). Elsevier, Amsterdam, p. 383396.

ANDOW, D. 1991. Vegetational diversity and arthropod population response. A. Rev. Ent. 36:561-586.

BROWN Jr., K.S. 1997. Diversity, disturbance, and sustainable use of neotropical forests: insects as indicators for conservation monitoring. J. Insect Conserv. 1:25-42.

CESAR, O. \& LEITÃO FILHO, H.F. 1990. Estudo florístico quantitativo de mata mesófila semidecídua na fazenda Barreiro Rico, município de Anhembi, SP. Revta bras. Biol. 50:133-147.

COSTA, M.B.B. da. 1993. Princípios da agricultura alternativa. In Simpósio de Agricultura Ecológica. Fundação Cargill, Campinas, p. 1-16.

DELUCCHI, V. 1989. Integrated pest management vs systems management. In Biological control: a sustainable solution to crop pest problems in Africa. Proc. Inaugural Conference and Workshop IITA Biological Control Program Center for Africa, 5-9 December 1988 (J.S. Yaninek \& H.R. Herren, ed.). Cotonou, Benin, p. 51-67.

FERES, R.J.F. 1992. A new species of Calacarus Keifer (Acari, Eriophyidae, Phyllocoptinae) from $H$. brasiliensis Muell. Arg. (Euphorbiaceae) from Brazil. Int. J. Acarology 18:61-65.
FERES, R.J.F. 2000. Levantamento e observações naturalísticas da acarofauna (Acari, Arachnida) de seringueiras cultivadas (Hevea spp., Euphorbiaceae) no Brasil. Revta bras. Zool. 17:157-173.

ERES, R.J.F. 2001. Primeiro registro de ácaros eriofiídeos (Acari, Eriophyidae) em seringueiras (Hevea brasiliensis Muell. Arg., Euphorbiaceae) da Floresta Amazônica, Brasil. Revta bras. Zool. 18:343-345.

JEPPSON, L.R., KEIFER, H.H. \& BAKER, E.W. 1975. Mites Injurious to Economic Plants. University of California Press, Berkeley. 679 p.

KRANTZ, G.W. 1978. A Manual of Acarology. 2nd ed. Oregon State University Book Stores Inc., Corvallis. 509 p.

LASALLE, J. \& GAULD, I.D. 1991. Hymenoptera: their diversity, and their impact on the diversity of other organisms. In Hymenoptera and Biodiversity ( $\mathrm{J}$. Lasalle \& I.D. Gauld, ed.). CAB International, Wellington, p. 1-26.

NOGUEIRA, J.C.B. 1976. A flora do município de Bauru. Silvicultura S. Paulo 10:45-54.

ODUM, E.P. 1988. Ecologia. Ed. Guanabara S.A., Rio de Janeiro. $434 \mathrm{p}$.

PONTIER, K.J.B. \& FLECHTMANN, C.H.W. 1999. Description of male Tenuipalpus heveae Baker, 1945 (Acari: Prostigmata: Tenuipalpidae). Int. J. Acarol., 25(4): 293-296.

SALIS, S.M., TAMASHIRO, J.Y. \& JOLY, C.A. 1994. Florística e fitossociologia do estrato arbóreo de um remanescente de mata ciliar do rio Jacaré-Pepira, Brotas, SP. Revta bras. Botânica 17:93-103.

SILVEIRA NETO, S., NAKANO, O., BARBIN, D. \& VILLA NOVA, N.A. 1976. Manual de Ecologia dos Insetos. Ed. Agronômica Ceres Ltda., São Paulo. 419 p.

Van den BOSCH, R., MESSENGER, P.S. \& GUTIERREZ, A.P. 1982. An Introduction to Biological Control. Plenum Press, New York. 247 p.

WALTER, D.E. \& O'DOWD, D.J. 1995. Life on the forest phylloplane: hairs, little houses, and myriad mites. In Forest Canopies (M.D. Lowman \& N.M. Nadkarni, ed.). Academic Press, San Diego, p. 325-351.

ZACARIAS, M.S. \& OLIVEIRA, A.R. 2000. Coletor de ácaros por sucção. Anais Soc. Ent. Bras. 29:827-830.

Title: MITE DIVERSITY (ARTHROPODA: ACARI) ON EUPHORBIACEOUS PLANTS

Authors: Mauricio Zacarias \& Gilberto Moraes

Biota Neotropica, Vol. 2( number 2): 2002

Http://www.biotaneotropica.org.br/v2n2/pt/abstract?artic le+BN00802022002

Date Received 04/26/2002 - Revised 07/22/2002

Accepted 07/27/2002

ISSN 1676-0611 


\begin{tabular}{|c|c|c|c|c|c|c|c|c|c|c|c|c|c|c|c|}
\hline \multirow[b]{2}{*}{ Mite taxa } & Cananéia & \multicolumn{6}{|c|}{ Pariquera-Açu } & \multicolumn{8}{|c|}{ Piracicaba } \\
\hline & 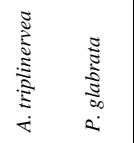 & 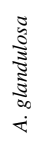 & 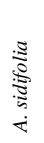 & 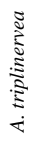 & 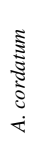 & 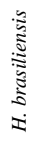 & 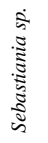 & 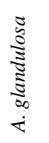 & 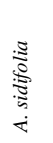 & 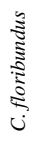 & 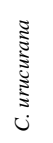 & 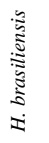 & 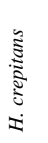 & 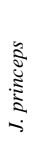 & 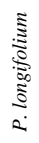 \\
\hline \multicolumn{16}{|l|}{ Acaridida } \\
\hline \multicolumn{16}{|l|}{ Acaridae: } \\
\hline Neotropacarus sp. & 4 & 1 & 23 & 3 & 14 & 44 & 4 & 59 & 53 & 26 & 43 & 54 & & 1 & 25 \\
\hline \multicolumn{16}{|l|}{ Winterschmidtiidae: } \\
\hline Czenspinskia sp. & 31 & 5 & 4 & 2 & 33 & 27 & & 139 & 13 & 94 & 34 & 2 & 38 & & 12 \\
\hline Oulenzia sp. & & 1 & 17 & & & 9 & & 730 & 18 & 7 & & & 1 & 2 & 11 \\
\hline \multicolumn{16}{|l|}{ Actinedida } \\
\hline \multicolumn{16}{|l|}{ Cunaxidae: } \\
\hline Cunaxa sp. & & & & & & & & & & 26 & & & & & \\
\hline Cunaxoides sp. & & & & & & & 1 & & & & & & & & \\
\hline Neocunaxoides sp. & & 20 & 6 & 13 & & & 1 & & & & & & & & \\
\hline Pulaeus sp. & & 5 & 2 & 1 & 48 & 1 & & & & & & & & & \\
\hline Scirula sp. & 1 & 1 & & & & & & & & & & & & & \\
\hline Scutopalus sp. & & 47 & & 15 & 102 & 3 & 5 & & & & & & & & \\
\hline \multicolumn{16}{|l|}{ Cheyletidae: } \\
\hline Cheyletia sp. & & & & & & & & & & 2 & & 3 & 1 & & 4 \\
\hline \multicolumn{16}{|l|}{ Stigmaeidae: } \\
\hline Agistemus sp. & 9 & 2 & & 9 & 12 & 2 & 5 & 22 & & 24 & 7 & 5 & 29 & 1 & 93 \\
\hline Eryngiopus sp. & & & & & & & & & & & & & & & 1 \\
\hline Ledermuelleria sp. & & & & & & & & 1 & & & & & & & \\
\hline Zetzellia sp. & 1 & & & & 1 & & & & & & & 17 & 1 & & 2 \\
\hline \multicolumn{16}{|l|}{ Eupalopsellidae: } \\
\hline Exothorhis sp. & & & & & & & & & & 2 & & & & & \\
\hline \multicolumn{16}{|l|}{ Eupodidae: } \\
\hline Eupodes sp. & & 1 & & & 1 & & 1 & 1 & & 1 & & & & & \\
\hline \multicolumn{16}{|l|}{ Tarsonemidae: } \\
\hline Daidalotarsonemus sp. & & & & & 1 & & 1 & & & 1 & & & & & \\
\hline Fungitarsonemus sp. & 10 & 1 & & & 1 & & 21 & 4 & & & & & & 1 & \\
\hline Tarsonemus (T.) sp. & 2 & 1 & 3 & 4 & 1 & 14 & 3 & 92 & 148 & 302 & 1 & & 1 & 2 & 1 \\
\hline Xenotarsonemus sp.1 & & & & & 89 & & & & & & & & & & \\
\hline Xenotarsonemus sp. 2 & & 20 & & 1 & 69 & 1 & & & & & & & & & \\
\hline Xenotarsonemus sp. 3 & & & & & 1 & & & & & & & & & & \\
\hline Xenotarsonemus sp. 4 & & 1 & & & & & & & & & & & & & \\
\hline Xenotarsonemus sp.5 & & & & & & & & 1 & & & & & & & \\
\hline \multicolumn{16}{|l|}{ Tenuipalpidae: } \\
\hline Brevipalpus sp. & & & 19 & 1 & 15 & 44 & 2 & 15 & & 539 & 247 & & & 1 & 7 \\
\hline Tenuipalpus sp. & & & & & & & & & & 1 & & & & & \\
\hline \multicolumn{16}{|l|}{ Tetranychidae: } \\
\hline Allonychus reisi Paschoal & & & & & 65 & & & 6 & & & 1 & & & 2 & \\
\hline Eutetranychus banksi (McGregor) & & & & & 11 & 12 & & & & & & 17 & & & \\
\hline Neotetranychus sp. & & & & & & & & & & 440 & & & & & \\
\hline Oligonychus gossypii (Zacher) & & & & & & & & & 6 & & 10 & 69 & & & \\
\hline Oligonychus sp. & & 2 & 11 & & 21 & & & & & & & & & & \\
\hline Tetranychus (T.) sp. & & & & & 22 & & & & & & & & 15 & & \\
\hline Diptilomiopidae: & & & & & & & & & & & & & & & \\
\hline Asetadiptacus sp. & & 3 & & 7 & & & & & 3102 & 350 & & & & & 38 \\
\hline
\end{tabular}

http://www.biotaneotropica.org.br 


\begin{tabular}{|c|c|c|c|c|c|c|c|c|c|c|c|c|c|c|c|c|}
\hline \multirow[b]{2}{*}{ Mite taxa } & \multicolumn{2}{|c|}{ Cananéia } & \multicolumn{6}{|c|}{ Pariquera-Açu } & \multicolumn{8}{|c|}{ Piracicaba } \\
\hline & 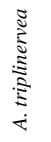 & 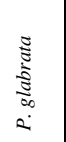 & 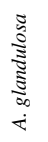 & 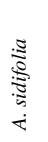 & 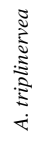 & 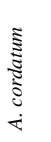 & 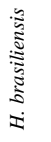 & 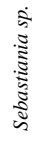 & 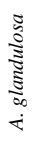 & 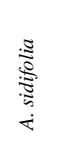 & 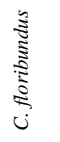 & 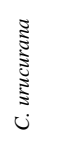 & 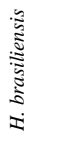 & 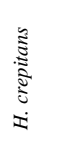 & 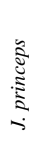 & 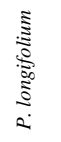 \\
\hline \multicolumn{17}{|l|}{ Eriophyidae: } \\
\hline Calacarus heveae Feres & & & & & & & 3 & & & & & & 349 & & & \\
\hline Calacarus sp. & & & & & & 6 & & & & & & & & & & \\
\hline Epitrimerus goniathrix Micos \& Flechtmann & & & & & & & & & & & & & & 1325 & & \\
\hline Eriophyes sp. & & & & & & & & & & & & & & & & 187 \\
\hline Eriophyidae (sp.1) & & & & & & & & & & & & & & & & 1412 \\
\hline Paraphytella sp. & & & & & & & & & & & & 1341 & & & & \\
\hline Paraphytoptus sp. & & & & & & & & & & & 8351 & & & & & \\
\hline Phyllocoptinae (sp.1) & 3 & & & 1 & & & & & 400 & 1110 & & & & & & \\
\hline Phyllocoptinae (sp.2) & & & & & & & & & 230 & 200 & & & & & & \\
\hline Shevtchenkella sp. & & & & & & & & & 3 & & 108 & & & & & \\
\hline Tegonotus sp. & & & & & & & & & & & & & & & & 3 \\
\hline \multicolumn{17}{|l|}{ Tydeidae: } \\
\hline Afrotydeus sp. & & 2 & 2 & & 1 & 13 & & 64 & & & & & & & & \\
\hline cf. Homeopronematus sp. & & & & & & 1 & & & & & & & & & & \\
\hline cf. Krantzlorryia sp. & & & & & & 1 & & & & & & & & & & \\
\hline Lorryia formosa Cooreman & & & 33 & & 2 & & 155 & & 5 & 2 & 1 & & & 69 & 3 & 93 \\
\hline Lorryia sp.1 & 48 & 4 & 4 & & 16 & 7 & 6 & 3 & 129 & 97 & 391 & 282 & 859 & 712 & 462 & 1189 \\
\hline Lorryia sp. 2 & & & 6 & & & 71 & & & & & & & & & & \\
\hline Lorryia sp. 3 & & & 3 & & 5 & 24 & & & & & & & & & & \\
\hline Lorryia sp.4 & & & & & & 1 & & & & & & & & & & \\
\hline Lorryia sp.5 & & & & & & 1 & & & & & 1 & & & & & \\
\hline Lorryia sp.6 & & & & & & 1 & & & & & & & & & & \\
\hline Lorryia sp.7 & & 2 & 1 & & & & 2 & & & & & & & & & \\
\hline Lorryia sp. 8 & & & & 11 & & & & & & 3 & 143 & & & & 1 & \\
\hline cf. Lorryia sp. & & & 5 & & & & & & & & & & & & & \\
\hline cf. Metalorryia sp. & & & & & & 3 & & 2 & & & & & & & & \\
\hline cf. Metapronematus sp. & & & & & & & & & & & & & 2 & & & \\
\hline Meyerellinae (sp.1) & & & & & & & & & 1 & & & & & & & \\
\hline Meyerellinae (sp.2) & & & & & & 18 & & & & & 1 & & & 1 & & \\
\hline Neolorryia sp. & & & & & & & & & 1 & & & & & & & 13 \\
\hline Paralorryia shawi (Baker) & & & & & & & & & & & & & & & & 1 \\
\hline Parapronematus acaciae Baker & 1 & & 1 & & 4 & & 11 & 1 & 1 & & & 1 & 28 & 1 & & 2 \\
\hline Pausia sp. & & & & & & 1 & & & & & & & & & & \\
\hline Pretydeus curiosa (Ueckermann \& Smith-Meyer) & & & & & & & & & 3 & & & & 1 & & & \\
\hline Pretydeus reticulatus Flechtmann & & & 2 & & & 39 & & & & & & & & & & \\
\hline Pretydeus sp. & 4 & & 1 & & & & 2 & 9 & & & & & & & & \\
\hline Pronematus sp. & & & & & & & & & 1 & & & & 4 & & & \\
\hline cf. Pronematus sp. & & & & & & 6 & 3 & & & & & & 3 & & & \\
\hline Triophtydeus sp. & & 1 & & & & 3 & & & & & 2 & & & & & 1 \\
\hline Tydeus californicus (Banks) & & & & & & & 44 & & & & & & & & & \\
\hline Tydeus costensis Baker & & & & & & & 1 & & & & & & & & & \\
\hline \multicolumn{17}{|l|}{ Gamasida } \\
\hline \multicolumn{17}{|l|}{ Ameroseiidae: } \\
\hline ?Epicriopsis sp. & & & & & & & & & & & 13 & & & & & \\
\hline \multicolumn{17}{|l|}{ Ascidae: } \\
\hline Asca sp. & 11 & 3 & 38 & 9 & 4 & 355 & 1 & 1 & 33 & & & & & & & \\
\hline Phytoseiidae: & & & & & & & & & & & & & & & & \\
\hline
\end{tabular}

http://www.biotaneotropica.org.br 
Amblyseiulella sooretama (El-Banhawy) Amblyseius herbicolus (Chant)

Amblyseius impeltatus Denmark \& Muma

Amblyseius neochiapensis Lofego, Moraes \& McMurtry

Amblyseius operculatus DeLeon

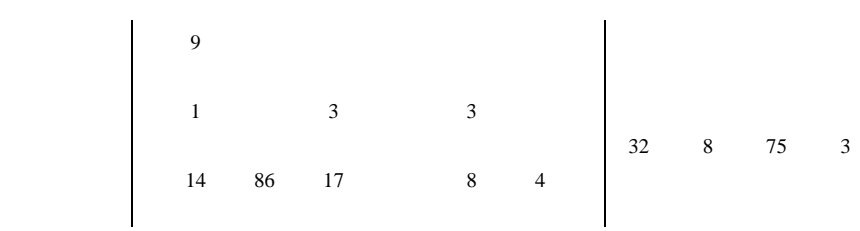

\begin{tabular}{|c|c|c|c|c|c|c|c|c|c|c|c|c|c|c|c|c|}
\hline \multirow[b]{2}{*}{ Mite taxa } & \multicolumn{2}{|c|}{ Cananéia } & \multicolumn{6}{|c|}{ Pariquera-Açu } & \multicolumn{8}{|c|}{ Piracicaba } \\
\hline & $\begin{array}{l}\Xi \\
\stackrel{\Xi}{\Xi} \\
\stackrel{\Xi}{\Xi} \\
:\end{array}$ & 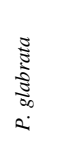 & 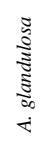 & 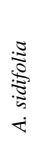 & 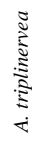 & 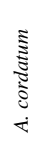 & 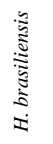 & 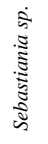 & 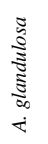 & 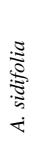 & 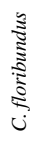 & 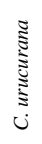 & 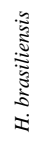 & 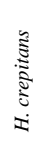 & 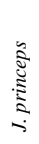 & 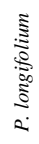 \\
\hline Amblyseius saopaulus Denmark \& Muma & & 3 & & 5 & 23 & & 1 & & & & & & & & & \\
\hline Euseius alatus DeLeon & & & & & 3 & & & & 52 & & 2 & & 6 & & 7 & 27 \\
\hline Euseius citrifolius Denmark \& Muma & & & & & & & & & & & & & 1 & 55 & 15 & 1 \\
\hline Euseius ho (DeLeon) & & & 32 & 26 & & & & & 67 & 19 & 31 & & & & & \\
\hline Galendromimus alveolaris (DeLeon) & & & & & & & & & 2 & & 25 & & & & & \\
\hline Galendromimus paulista Zacarias \& Moraes & & & & & & & & & & & 19 & & & & & \\
\hline Iphiseiodes zuluagai Denmark \& Muma & & & & & & & & & 66 & 15 & 244 & 7 & 1 & 11 & 11 & 57 \\
\hline Paraphytoseius multidentatus Swirski \& Shechter & & & 1 & & & 52 & & & 24 & & 17 & 1 & & & & \\
\hline Phytoscutus sexpilis Muma & & 1 & & & & & 16 & & 8 & 3 & & & & & & \\
\hline Phytoseius latinus El-Benhawy & & & & 6 & & & & & & & & & & & & \\
\hline Proprioseiopsis cannaensis (Muma) & & & & & & & & & & & & & & & & 5 \\
\hline Proprioseiopsis dominigos (El-Banhawy) & & & 1 & 1 & & 5 & 2 & & 2 & & & & & & & 19 \\
\hline Proprioseiopsis neotropicus (Ehara) & & & 9 & 10 & 4 & 34 & & & & & 7 & & & & & \\
\hline Proprioseius retroacuminatus Zacarias \& Moraes & & & & & & 56 & & & & & & & & & & \\
\hline Typhlodromalus aripo DeLeon & & & & & & & & & 1 & & & & & & & \\
\hline Typhlodromalus manihoti Moraes & & & & 16 & 24 & & & & & & & 6 & & & & \\
\hline Typhlodromalus peregrinus (Muma) & & & & & 11 & & & & & & & & & & & \\
\hline Typhlodromalus sp. & & & & & & 49 & & & & & & & & & & \\
\hline Typhlodromalus villacarmelensis Moraes & & & 12 & & & & & & & & & & & & & \\
\hline Typhlodromina camelliae (Chant \& Yoshida-Shaul) & & & & & & & & & & & & & 56 & 35 & 2 & 1 \\
\hline Typhlodromips cananeiensis Gondim Jr. \& Moraes & 23 & 7 & 9 & & 5 & & 107 & 1 & & & & & & & & \\
\hline Typhlodromips linharis El-Banhawy & & & & & & & & 13 & & & & & & & & \\
\hline Typhlodromips sp. & & & 10 & & & & & 10 & & & & & & & & \\
\hline Typhlodromus annectens DeLeon & & & & 13 & & & & & 21 & & 1 & & & & & \\
\hline
\end{tabular}

Table 1. Number of specimens of each mite taxa (Arthropoda: Acari) collected in 1998 from euphorbiaceous plants (Euphorbiaceae) in localities of the State of São Paulo. 


\begin{tabular}{|c|c|c|c|c|c|c|c|c|c|c|c|c|c|c|c|c|c|c|c|c|c|c|c|c|}
\hline \multirow[t]{2}{*}{ Locality } & \multirow[t]{2}{*}{ Plant species } & \multicolumn{3}{|c|}{$\begin{array}{l}\text { Proportion of the } \\
\text { total second food } \\
\text { habit (\%) }\end{array}$} & \multicolumn{4}{|c|}{$N$ (number of specimens) } & \multicolumn{4}{|c|}{$S$ (number of species) } & \multicolumn{4}{|c|}{$\begin{array}{c}H \text { (Shannon-Weiner } \\
\text { diversity index) }\end{array}$} & \multicolumn{4}{|c|}{$\begin{array}{c}e \text { (Pielou uniformity } \\
\text { index of species) }\end{array}$} & \multicolumn{4}{|c|}{$\begin{array}{c}d \text { (Pielou richness index } \\
\text { of species) }\end{array}$} \\
\hline & & $\%_{\mathrm{p}}$ & $\%_{\mathrm{f}}$ & $\% \mathrm{~g}$ & $N$ & $N_{\mathrm{p}}$ & $N_{\mathrm{f}}$ & $N_{\mathrm{g}}$ & $S$ & $S_{\mathrm{p}}$ & $S_{\mathrm{f}}$ & $S_{\mathrm{g}}$ & $H$ & $H_{\mathrm{p}}$ & $\boldsymbol{H}_{\mathrm{f}}$ & $\boldsymbol{H}_{\mathrm{g}}$ & $e$ & $e_{\mathrm{p}}$ & $e_{\mathrm{f}}$ & $e_{\mathrm{g}}$ & $d$ & $d_{\mathrm{p}}$ & $d_{\mathrm{f}}$ & $d_{\mathrm{g}}$ \\
\hline \multirow[t]{2}{*}{ Cananéia } & A. triplinervea & 33 & 2 & 65 & 138 & 45 & 3 & 90 & 12 & 5 & 1 & 6 & 0.80 & 0.51 & 0.00 & 0.48 & 0.74 & 0.73 & - & 0.62 & 5.14 & 2.42 & 0.00 & 2.56 \\
\hline & P. glabrata & 42 & - & 58 & 33 & 14 & 0 & 19 & 9 & 4 & 0 & 5 & 0.84 & 0.52 & 0.00 & 0.56 & 0.88 & 0.86 & - & 0.80 & 5.27 & 2.62 & 0.00 & 3.13 \\
\hline \multirow[t]{6}{*}{ Pariquera-Açu } & A. glandulosa & 69 & 2 & 29 & 305 & 211 & 5 & 89 & 36 & 16 & 2 & 18 & 1.25 & 0.99 & 0.29 & 0.91 & 0.80 & 0.82 & 0.97 & 0.72 & 14.09 & 6.45 & 1.43 & 8.72 \\
\hline & A. sidifolia & 66 & 12 & 22 & 269 & 180 & 31 & 58 & 19 & 11 & 3 & 5 & 1.05 & 0.76 & 0.34 & 0.60 & 0.82 & 0.73 & 0.71 & 0.86 & 7.41 & 4.43 & 1.34 & 2.27 \\
\hline & A. triplinervea & 74 & 5 & 21 & 178 & 132 & 8 & 38 & 24 & 13 & 2 & 9 & 1.21 & 0.99 & 0.16 & 0.78 & 0.88 & 0.89 & 0.54 & 0.82 & 10.22 & 5.66 & 1.11 & 5.06 \\
\hline & A. cordatum & 57 & 11 & 32 & 1254 & 714 & 140 & 400 & 40 & 10 & 6 & 24 & 1.20 & 0.71 & 0.65 & 0.99 & 0.75 & 0.71 & 0.84 & 0.72 & 12.59 & 3.15 & 2.33 & 8.84 \\
\hline & H. brasiliensis & 28 & 11 & 61 & 522 & 144 & 59 & 319 & 26 & 10 & 3 & 13 & 0.99 & 0.44 & 0.30 & 0.73 & 0.70 & 0.44 & 0.63 & 0.65 & 9.20 & 4.17 & 1.13 & 4.79 \\
\hline & Sebastiania sp. & 27 & 1 & 72 & 152 & 41 & 2 & 109 & 20 & 9 & 1 & 10 & 0.92 & 0.79 & 0.00 & 0.59 & 0.70 & 0.82 & - & 0.59 & 8.71 & 4.96 & 0.00 & 4.42 \\
\hline \multirow[t]{8}{*}{ Piracicaba } & A. glandulosa & 10 & 54 & 36 & 3220 & 331 & 1722 & 1167 & 33 & 13 & 6 & 14 & 0.92 & 0.92 & 0.42 & 0.54 & 0.61 & 0.83 & 0.54 & 0.47 & 9.12 & 4.76 & 1.55 & 4.24 \\
\hline & A. sidifolia & 1 & 92 & 7 & 4797 & 45 & 4481 & 334 & 15 & 4 & 4 & 7 & 0.48 & 0.53 & 0.32 & 0.59 & 0.41 & 0.88 & 0.54 & 0.70 & 3.80 & 1.81 & 0.82 & 2.38 \\
\hline & C. floribundus & 4 & 87 & 9 & 11247 & 488 & 9789 & 970 & 32 & 14 & 6 & 12 & 0.52 & 0.76 & 0.26 & 0.62 & 0.34 & 0.66 & 0.34 & 0.57 & 7.65 & 4.84 & 1.25 & 3.68 \\
\hline & C. urucurana & 1 & 81 & 18 & 1984 & 24 & 1599 & 361 & 14 & 5 & 4 & 5 & 0.46 & 0.63 & 0.21 & 0.30 & 0.40 & 0.91 & 0.34 & 0.44 & 3.94 & 2.90 & 0.94 & 1.56 \\
\hline & H. brasiliensis & 6 & 30 & 65 & 1477 & 89 & 435 & 953 & 18 & 7 & 3 & 8 & 0.58 & 0.51 & 0.26 & 0.19 & 0.46 & 0.60 & 0.54 & 0.21 & 5.36 & 3.08 & 0.76 & 2.35 \\
\hline & H. crepitans & 6 & 58 & 36 & 2295 & 132 & 1340 & 823 & 15 & 6 & 2 & 7 & 0.50 & 0.58 & 0.03 & 0.22 & 0.42 & 0.74 & 0.09 & 0.26 & 4.17 & 2.36 & 0.32 & 2.06 \\
\hline & J.princeps & 7 & 1 & 92 & 511 & 36 & 3 & 472 & 14 & 5 & 2 & 7 & 0.22 & 0.57 & 0.28 & 0.06 & 0.19 & 0.81 & 0.92 & 0.07 & 4.80 & 2.57 & 2.10 & 2.24 \\
\hline & P. longifolium & 7 & 51 & 42 & 3221 & 226 & 1647 & 1348 & 26 & 11 & 5 & 10 & 0.64 & 0.71 & 0.22 & 0.23 & 0.45 & 0.68 & 0.31 & 0.23 & 7.13 & 4.25 & 1.24 & 2.88 \\
\hline \multicolumn{25}{|c|}{ Euforbiaceous species group } \\
\hline \multicolumn{2}{|c|}{ Group 1} & 52 & 9 & 39 & 2851 & 1481 & 248 & 1122 & 71 & 28 & 9 & 34 & 1.54 & 1.12 & 0.77 & 1.23 & 0.83 & 0.78 & 0.80 & 0.80 & 20.26 & 8.52 & 3.34 & 10.82 \\
\hline \multicolumn{2}{|c|}{ Group 2} & 5 & 73 & 22 & 28752 & 1371 & 20953 & 6428 & 67 & 26 & 19 & 22 & 1.12 & 1.06 & 0.87 & 0.56 & 0.61 & 0.75 & 0.68 & 0.42 & 14.80 & 7.97 & 4.17 & 5.51 \\
\hline
\end{tabular}

Table 2. Ecological parameters of mites collected in Cananéia, Pariquera-Açu and Piracicaba, State of São Paulo, in 1998.\% mites; \% proportion of phytophagous mites; $\%_{g}$ : proportion of generalist mites; $N$ : total number of specimens; S: total number of species; H: ShannonWeiner species diversity index; $e$ : Pielou species uniformity index; : Pielou species richness index; subscripts $p$, f and $g$ indicate the corresponding indices for predaceous, phytophagous and generalist mites, respectively. 